\title{
THE STRUCTURE OF CONSUMER SEGMENTS IN THE MARKET OF MOTOR OIL FOR PASSENGER CARS
}

\author{
Aleksander LOTKO $^{1 *}$, Małgorzata LOTKO², Magdalena ZWIERZCHOWSKA ${ }^{3}$ \\ ${ }^{1}$ University of Technology and Humanities, Faculty of Chemical Engineering and Commodity Science, Poland; \\ aleksander.lotko@uthrad.pl, ORCID: 0000-0003-4420-7495 \\ ${ }^{2}$ University of Technology and Humanities, Faculty of Chemical Engineering and Commodity Science, Poland; \\ m.lotko@uthrad.pl, ORCID: 0000-0002-3704-1119 \\ ${ }^{3}$ University of Technology and Humanities, Faculty of Chemical Engineering and Commodity Science, Poland; \\ zwierzchowska.magdalena@o2.pl, ORCID: 0000-0001-5955-5412 \\ * Correspondence author
}

Purpose: The purpose of this paper was to identify the structure of consumer segments in the market of motor oil for passenger cars.

Design/methodology/approach: A quantitative approach was applied. A questionnaire-based research was carried out. Cluster analysis was selected as the results elaboration method.

Findings: It was discovered that, when considering consumer behavioural loyalty, four market segments (clusters) were identified. They are characterized by different values of formal features: four features concerning the consumer and five features concerning the vehicle and its maintenance.

Practical implications: A practical implication of the study is revealing the structure of consumer segments in the researched market and describing their characteristics. This knowledge can be used in differentiating marketing activities for each of the identified segments in order to ensure that these activities are more efficient.

Originality/value: Authors' contribution and novelty of the paper is the innovative application of one of the multidimensional exploratory techniques, cluster analysis, in the area of research. In management practice, the paper can be useful for marketing managers in the automotive industry, especially motor oil manufacturers.

Keywords: market heterogeneity, consumer segmentation, consumer loyalty, automotive market, motor oil, cluster analysis.

Category of the paper: research paper. 


\section{Introduction}

Today's observed striving for the increase of the reliability of motor cars engines results in the constant improvement of the requirements regarding the quality parameters of the manufactured oils and further modifications of quality classification. Consumers expect a modern engine that is cost-effective and durable, and at the same time, presents satisfactory performance throughout the entire exploitation period with extended intervals of motor oil exchange.

The above mentioned expectations are to be met by the car and lubricant manufacturers as they treat oil as an important engine construction element that determines its performance, usability features, reliance, durability and the volume of the emission of toxic ingredients of exhaust fumes. Modern motor oils must also constantly follow motor construction changes, as well as the introduction of new fuels and even stricter environment protection requirements (Lotko, Lotko, and Lotko, 2020). The specifics of this market are catered to through market segmentation.

Next to mass marketing and inventory marketing (Kotler, 1994; Dziechciarz, 2009), marketing of the segments of the market is another development level of this particular field of knowledge, initiated almost five hundred years ago (Smith, 1956). The market segmentation concept is based on the division of a heterogeneous market, i.e. the diverse market into smaller and more homogenous segments, i.e. homogenous segments (Mynarski, 1993). Herein, the great diversification of consumers is seen in their huge diversity of preferences, specific behaviours as well as demands. This diversification of behaviours creates the need for the search of common features that are appropriate for specific groups of consumers, and, at the same time, distinguishes the said groups from the entire community (Żuchowski, 2007).

Market segmentation consists in the division of the market according to the specific criteria into the possibly homogenous groups of purchasers, i.e. market segments requiring the application of different strategies and marketing tools in order to exert an influence on the shopping habits of the purchasers (Kotler, 1994; Encyklopedia zarządzania, 2019). Therefore, market segmentation is the division of the market in accordance with specific criteria, into the groups of entities (Smyczek, 2000). The rule of segmentation is reasonable diversification of marketing resources accommodating diversified needs (Assael, and Roscoe, 1976). Particular groups of consumers have various expectations towards the products, as well as reactions to the applied marketing strategies and tools (Pawlak, 1992). In order to satisfy the diversified needs of the consumers, the market must be divided into a relatively homogenous groups, and, subsequently, the marketing offer should be adjusted to the enumerated segments. Therefore segmentation is the basis for the diversification of marketing operations (Szulce, Florek, and Walkowiak, 2004). Thus, the supply is adjusted to the need. 
Market segments are created due to the following main reasons (Dziechciarz, 2009; Grzywacz, 2014):

- simplification of the selection of a market in which a business activity is profitable which eases the burden of strategic planning and marketing operations,

- better adjustment to consumer's needs,

- easier observation of changes taking place in the market,

- simplification of communication between the manufacturer and consumers,

- easier access to consumers whose preferences were considered in the formation of marketing operations.

In connection with the above, the purpose of this paper was to identify the structure of the segments of consumers in the market of one of the most important motor exploitation materials - motor oils.

\section{Lubricating oils market in Poland}

In 2018, the lubricating oils market in Poland has reached a sales volume of 234624 tons, what means an increase by $3,33 \%$ in respect of the year 2017 . The volume of the lubricating oils market in the years 2005-2018 is presented in Figure 1.

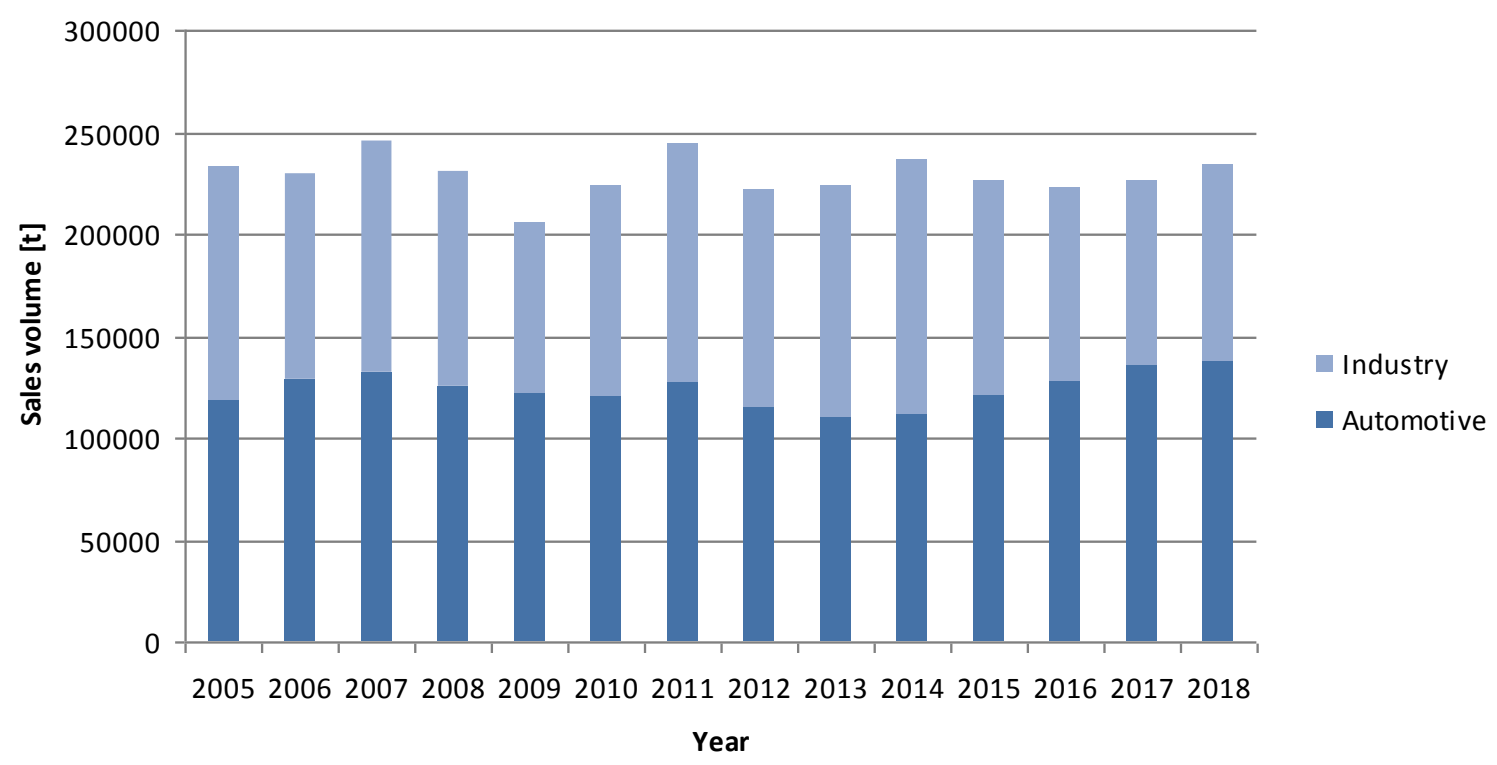

Figure 1. The entire lubricating oils market $(\mathrm{t})$ in Poland in the years 2005-2018. Source: (POPiNH, 2018).

In 2018, over 108604 tons of lubricating oils of all types were sold in Poland. One year earlier, it was around 109057 tons, therefore, this level remained practically unchanged. The yearly average sale in the analysed segment in the previous 12 years was 101 369 tons (POPiNH, 2018). 
Motor oils manufactured for the automotive industry constitute around 46,5\% of all lubricating oils sold in Poland. In the automotive industry segment, it is around $80 \%$ (Kierunek Chemia, 2015). We should emphasize the fact concerning the increase of the sale of synthetic oils for passenger cars on the entire market scale has gone from $5,5 \%$ in 2007 , to $18,34 \%$ in 2018. In the structure of the sale of motor oils, in which we observe significant changes connected with modernization of the car fleet over the last 12 years, the share of synthetic oils and semi-synthetic oils, and, therefore, the share of oils of lower and average stickiness, is constantly growing (POPiNH, 2018).

In the Polish market, there are several leading lubricant oils manufacturers catering to the automotive industry. The offered products vary in respect of the price, quality and technical parameters. In Table 1 we present the classification of 20 brands of motor oils evaluated by the participants of the program 'Selection of the drivers' as the best.

\section{Table 1.}

Classification of the brands of motor oils evaluated by the participants of the program 'Selection of the drivers' as the best in 2018

\begin{tabular}{|c|c|c|c|c|}
\hline Rank & Brand & Score & Change \% & Rank change \\
\hline 1 & Motul & $78,1 \%$ & $0,1 \%$ & $>0$ \\
\hline 2 & Valvoline & $77,2 \%$ & $1,0 \%$ & $>0$ \\
\hline 3 & Liqui Moly & $76,5 \%$ & $2,7 \%$ & $\Delta 1$ \\
\hline 4 & Petronas & $74,3 \%$ & $8,4 \%$ & $\Delta 4$ \\
\hline 5 & Total & $73,7 \%$ & $-0,7 \%$ & $\nabla-2$ \\
\hline 6 & Mobil & $71,6 \%$ & $4,5 \%$ & $>0$ \\
\hline 7 & Shell & $68,7 \%$ & $2,4 \%$ & $>0$ \\
\hline 8 & Castrol & $65,2 \%$ & $1,7 \%$ & $\Delta 1$ \\
\hline 9 & Millers Oils & $63,9 \%$ & $1,8 \%$ & $\Delta 1$ \\
\hline 10 & Elf & $61,6 \%$ & $8,3 \%$ & $\Delta 3$ \\
\hline 11 & Orlen & $57,4 \%$ & $9,8 \%$ & $\Delta 5$ \\
\hline 12 & $\mathrm{BP}$ & $55,2 \%$ & $12,7 \%$ & $\Delta 6$ \\
\hline 13 & Fuchs & $54,7 \%$ & $-4,1 \%$ & $\nabla-2$ \\
\hline 14 & Lotos & $52,8 \%$ & $4,8 \%$ & $\Delta 1$ \\
\hline 15 & Aral & $50,2 \%$ & - & - \\
\hline 16 & Repsol & $46,3 \%$ & - & - \\
\hline 17 & Ford & $45,9 \%$ & $-12,0 \%$ & $\nabla-5$ \\
\hline 18 & BMW & $44,4 \%$ & $-0,5 \%$ & $\nabla-1$ \\
\hline 19 & Mazda & $42,5 \%$ & - & - \\
\hline 20 & Pennasol & $39,8 \%$ & - & - \\
\hline
\end{tabular}

Source: (Wybór Kierowców, 2019).

Table 1 shows that in 2018 such brands as Aral, Respol, Mazda and Pennasol have appeared in the ranking for the first time. The following brands were evaluated at the highest level: Motul, Valvoline and Liqui Moly, whereas Pennasol at the lowest level. Last year's position was maintained by the products of Motul, Valvoline, Mobil and Shell. The most spectacular promotion (6 positions) was gained by $B P$, whereas the greatest decrease was observed in the case of Ford oils (5 positions). The complete ranking of lubricant oils manufacturers is presented in Figure 2. 


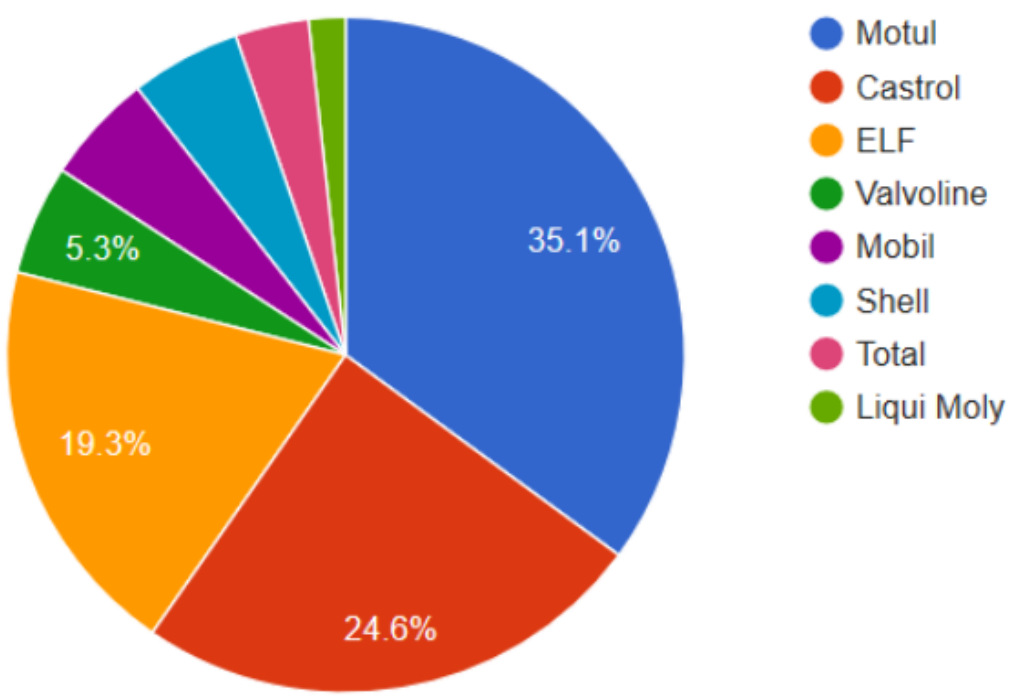

Figure 2. Ranking of the popularity of the motor oil manufacturers. Source: (Webranking, 2019).

According to the information published on the webranking.pl portal (Webranking, 2019) in the motor oil category, the most popular are the products made by Motul (share of 35,1\%), Castrol (24,6\%) and Elf (19,3\%).

\section{Methodology of the study}

In order to succeed, we created a seven-stage procedure of preparing and carrying out the empirical study and the analysis of the obtained results. It is presented in Table 2.

\section{Table 2.}

Research procedure

\begin{tabular}{|c|l|l|}
\hline No. & \multicolumn{1}{|c|}{ Task } & \multicolumn{1}{|c|}{ Methods, techniques, tools } \\
\hline 1 & $\begin{array}{l}\text { Conceptualization of the research area: } \\
\text { identification of the research problem and research } \\
\text { gap, specification of research problems, aim and } \\
\text { hypotheses. }\end{array}$ & $\begin{array}{l}\text { Critical analysis of literature, observation of the } \\
\text { economic reality, description. }\end{array}$ \\
\hline 2 & $\begin{array}{l}\text { Selection of variables and preparation of the } \\
\text { research tool. }\end{array}$ & Critical analysis of literature. \\
\hline 3 & Sampling. & $\begin{array}{l}\text { Population formula, significance level } \alpha=0,95, \\
\text { error } \beta=0,05, \text { population } n=384 ; \text { snowball } \\
\text { sampling. }\end{array}$ \\
\hline 4 & Conduct of the empirical study. & $\begin{array}{l}\text { Traditional questionnaire (printed } \\
\text { questionnaire). }\end{array}$ \\
\hline 5 & $\begin{array}{l}\text { Segmentation of consumers with the use of the } \\
\text { cluster analysis. }\end{array}$ & $\begin{array}{l}\text { Cluster analysis: (1) agglomeration (Ward } \\
\text { algorithm used for specification of the number } \\
\text { of clusters), (2) } k \text {-means method. }\end{array}$ \\
\hline 6 & Specification of the structure of segments. & Pivotal tables. \\
\hline 7 & Conclusions. & Synthesis. \\
\hline
\end{tabular}

Source: authors' own study. 
The first stage of the empirical study procedure was the literature review. Following this, we formulated a questionnaire. The first section includes certificate questions characterizing the consumer and the manner in which he/she uses the vehicle. It covers 9 positions (potentially differentiating variables), including 4 positions characterizing the consumer and 5 positions characterizing the vehicle and the manner of its use. Subsequently, we studied the motivation loyalty of the consumers specified by the $\mathrm{L}$ indicator (tendencies of recommending the product to friends) based on the Net Promoter Score (NPS) (Reichheld, 2003).

The study covered 384 users of a variety of passenger cars. The population was specified with the use of the formula for significance level $\alpha=0,95$ and error $\beta=0,05$. We applied a printed questionnaire. The study was carried out in the period from the $1^{\text {st }}$ to the $15^{\text {th }}$ September 2019.

In the classical approach, market segmentation applies classification methods, including, above all, hierarchical methods (Wedel, and Kamakura, 1998; Migut, 2004). Cluster analysis was the method applied in the formulation of the segmentation of consumers. It covers several different algorithms and methods used in the grouping of similar objects into similar categories. At first in order to elaborate the results of the study, we applied the agglomeration method (Ward algorithm) for the identification of the number of clusters and, thereafter, the $k$-means method (Gore, 2000) for the analysis of the structure of discovered clusters.

The structure of the consumer segments was worked out with the use of pivotal tables in the spreadsheet.

\section{Analysis of the results of the study - structure of the consumer segments}

Market segmentation covers several elements. They include the selection of the agglomeration base, the gathering of empirical material and the division of consumers into homogenous subgroups by means of the selected method of statistical multidimensional analysis. After the completion of the grouping stage, i.e. distinction of segments, particular segments were described due to the selected features. However, the understanding of the preferences and behaviours in the market, i.e. profile stage, enables the projection of the volume of demand for the offer addressed to the selected segments (Dziechciarz, 2009; Łapczyński, 2002).

In order to identify the number of segments, we applied cluster analysis in the form of the agglomeration method. Its results are presented in Figure 3. 


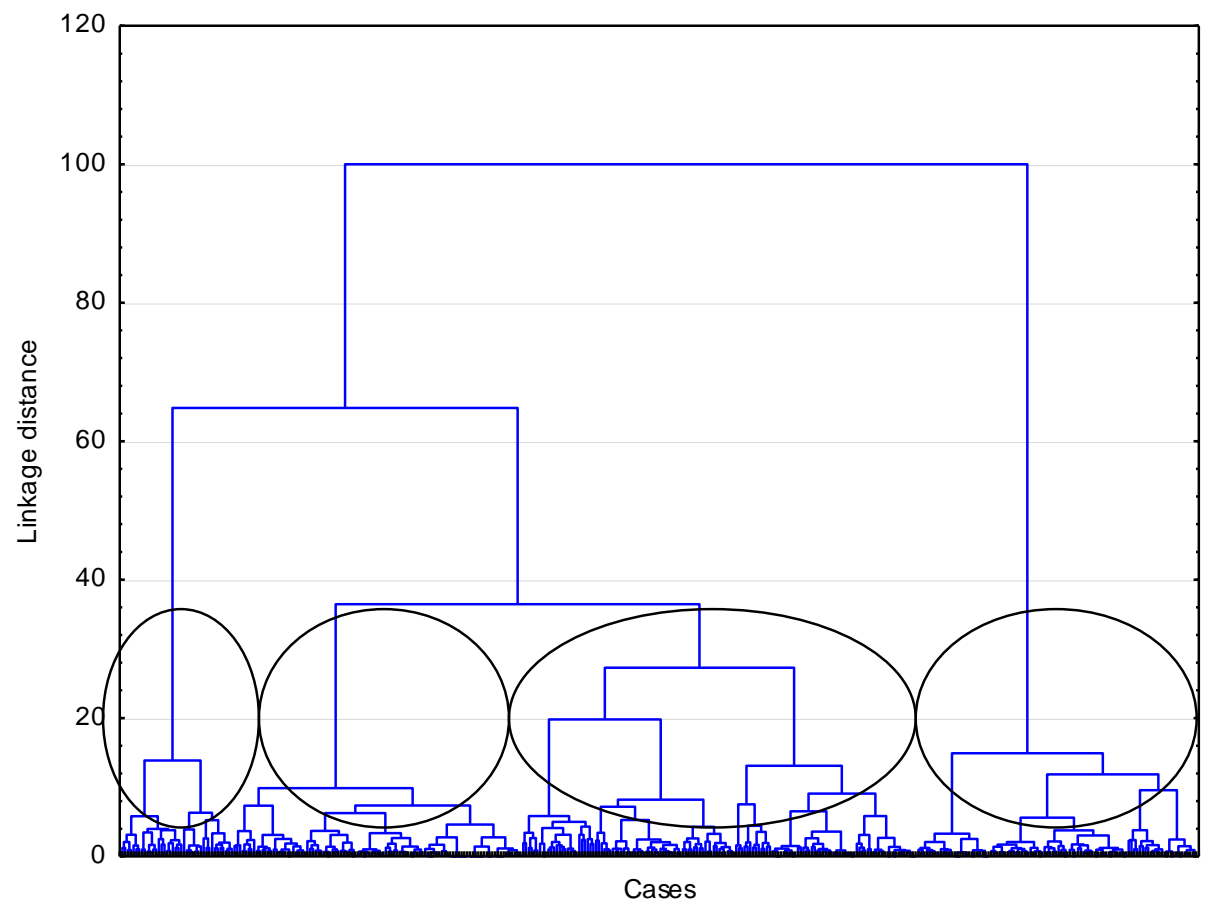

Figure 3. The results of the cluster analysis by means of the agglomeration method - icicle diagram. Source: authors' own study.

The analysis of Figure 3 induces the selection of a solution with 4 clusters, marked with ovals. In order to allocate consumers to a given segment, we then applied k-means algorithm.

Detailed data specifying the structures of the segments is presented in Tables 3-11 below.

Table 3.

Structure of segments on account of the sex of respondents

\begin{tabular}{|c|c|c|}
\hline Segment & Woman & Man \\
\hline $\mathbf{1}$ & $30 \%$ & $70 \%$ \\
\hline $\mathbf{2}$ & $16 \%$ & $84 \%$ \\
\hline $\mathbf{3}$ & $33 \%$ & $67 \%$ \\
\hline $\mathbf{4}$ & $36 \%$ & $64 \%$ \\
\hline In total & $31 \%$ & $69 \%$ \\
\hline
\end{tabular}

Source: authors' own study.

The analysis of Table 3 indicates that in respect of the sample, men outnumber women in segment 2 .

Table 4.

Structure of the segments on account of the age of respondents

\begin{tabular}{|c|c|c|c|}
\hline Segment & Up to 30 years & 31-50 years & Above 50 years \\
\hline $\mathbf{1}$ & $37 \%$ & $38 \%$ & $25 \%$ \\
\hline $\mathbf{2}$ & $64 \%$ & $24 \%$ & $12 \%$ \\
\hline $\mathbf{3}$ & $43 \%$ & $41 \%$ & $16 \%$ \\
\hline $\mathbf{4}$ & $57 \%$ & $31 \%$ & $13 \%$ \\
\hline In total & $50 \%$ & $33 \%$ & $17 \%$ \\
\hline
\end{tabular}

Source: authors' own study.

The analysis of Table 4 shows that in segment 1, i.e. rational promoters, we are dealing with a significantly bigger group of elderly people, i.e. above 50 years of age. In contrast, in segment 2, i.e. emotional promoters, young persons, i.e. up to 30 years of age, prevail. 
Table 5.

Structure of the segments on account of the education of respondents

\begin{tabular}{|c|c|c|c|}
\hline Segment & Elementary & Secondary & Higher \\
\hline $\mathbf{1}$ & $3 \%$ & $58 \%$ & $39 \%$ \\
\hline $\mathbf{2}$ & $5 \%$ & $67 \%$ & $28 \%$ \\
\hline $\mathbf{3}$ & $6 \%$ & $67 \%$ & $27 \%$ \\
\hline In total & $4 \%$ & $66 \%$ & $31 \%$ \\
\hline
\end{tabular}

Source: authors' own study.

On the basis of the analysis of Table 5, it can be said that in segment 1 there are more persons with higher education.

Table 6.

Structure of the segments on account of the membership of the group of drivers

\begin{tabular}{|c|c|c|c|c|c|c|}
\hline \multirow{2}{*}{ Segment } & \multicolumn{5}{|c|}{ Group of drivers } \\
\cline { 2 - 7 } & $\begin{array}{c}\text { The best in } \\
\text { class }\end{array}$ & Ecological & Sportsmen & Practical & Provident & $\begin{array}{c}\text { Cost- } \\
\text { effective }\end{array}$ \\
\hline $\mathbf{1}$ & $7 \%$ & $16 \%$ & $10 \%$ & $35 \%$ & $11 \%$ & $21 \%$ \\
\hline $\mathbf{2}$ & $5 \%$ & $7 \%$ & $31 \%$ & $29 \%$ & $17 \%$ & $10 \%$ \\
\hline $\mathbf{3}$ & $8 \%$ & $8 \%$ & $16 \%$ & $31 \%$ & $10 \%$ & $27 \%$ \\
\hline $\mathbf{4}$ & $3 \%$ & $15 \%$ & $19 \%$ & $34 \%$ & $12 \%$ & $17 \%$ \\
\hline In total & $5 \%$ & $13 \%$ & $18 \%$ & $33 \%$ & $12 \%$ & $18 \%$ \\
\hline
\end{tabular}

The analysis of Table 6 leads to the conclusion that in segment 2, the fraction of drivers who name themselves as ,ecological” is significantly smaller than in the entire sample and at the same time bigger than the fraction of the drivers who classify themselves as 'sportsmen'. At the same time, the group of provident respondents is impressive. Finally in segment 3 there are distinctly more cost-effective drivers.

Table 7.

Structure of the segments on account of the car status on purchase

\begin{tabular}{|c|c|c|}
\hline \multirow{2}{*}{ Segment } & \multicolumn{2}{|c|}{ Car status } \\
\cline { 2 - 3 } & New & Used \\
\hline $\mathbf{1}$ & $28 \%$ & $72 \%$ \\
\hline $\mathbf{2}$ & $17 \%$ & $83 \%$ \\
\hline $\mathbf{3}$ & $31 \%$ & $69 \%$ \\
\hline $\mathbf{4}$ & $15 \%$ & $85 \%$ \\
\hline In total & $21 \%$ & $79 \%$ \\
\hline
\end{tabular}

Source: authors' own study.

On the basis of the analysis of Table 7 it is notable that in segment 3 , the percentage of car users who purchased new cars is definitely the highest and analogically the number of the drivers who bought used cars is lower. Segment 4 demonstrates opposite characteristics, where the users of used cars dominate. 
Table 8.

Structure of the segments on account of car's market segment

\begin{tabular}{|c|c|c|c|c|c|c|c|}
\hline \multirow{2}{*}{ Segment } & \multicolumn{7}{|c|}{ Group of drivers } \\
\cline { 2 - 8 } & $\mathbf{A}, \mathbf{B}$ & $\mathbf{C}$ & $\mathbf{D}$ & $\mathbf{E}$ & SUV & Van & Other \\
\hline $\mathbf{1}$ & $24 \%$ & $17 \%$ & $16 \%$ & $21 \%$ & $7 \%$ & $4 \%$ & $11 \%$ \\
\hline $\mathbf{2}$ & $14 \%$ & $19 \%$ & $26 \%$ & $22 \%$ & $5 \%$ & $7 \%$ & $7 \%$ \\
\hline $\mathbf{3}$ & $24 \%$ & $22 \%$ & $8 \%$ & $16 \%$ & $10 \%$ & $10 \%$ & $12 \%$ \\
\hline $\mathbf{4}$ & $28 \%$ & $33 \%$ & $14 \%$ & $13 \%$ & $5 \%$ & $4 \%$ & $4 \%$ \\
\hline In total & $24 \%$ & $24 \%$ & $15 \%$ & $17 \%$ & $6 \%$ & $5 \%$ & $8 \%$ \\
\hline
\end{tabular}

Source: authors' own study.

The analysis of Table 8 reveals that in segment 1 there are expressly more users of higher average class cars (E) and cars other than in the sample, whereas in segment 2, users of average class cars (D and E) dominate. Segment 3 groups above all owners of SUVs and vans which are much more popular here. In contrast, in segment 4 we are dealing with drivers of less expensive vehicles, mainly from the A and B cluster.

Table 9.

Structure of the segments on account of the age of a car

\begin{tabular}{|c|c|c|c|c|}
\hline \multirow{2}{*}{ Segment } & \multicolumn{4}{|c|}{ Age of a car } \\
\cline { 2 - 5 } & Up to 5 years & $\mathbf{6 - 1 0}$ years & $\mathbf{1 1 - 1 5}$ years & Above 15 years \\
\hline $\mathbf{1}$ & $47 \%$ & $27 \%$ & $13 \%$ & $13 \%$ \\
\hline $\mathbf{2}$ & $26 \%$ & $24 \%$ & $24 \%$ & $26 \%$ \\
\hline $\mathbf{3}$ & $45 \%$ & $14 \%$ & $24 \%$ & $18 \%$ \\
\hline $\mathbf{4}$ & $41 \%$ & $34 \%$ & $14 \%$ & $11 \%$ \\
\hline In total & $41 \%$ & $28 \%$ & $16 \%$ & $15 \%$ \\
\hline
\end{tabular}

Source: authors' own study.

When analysing Table 9, we reached a conclusion that in segment 1, persons using the newest cars (up to 5 years), dominate, whereas segment 2 is dominated by drivers of the oldest vehicles, i.e. aged above 15 years, and the users of the newest cars, i.e. up to 5 years, are the smallest group here. In segment 3 there is a relatively large fraction of owners of vehicles from 11 to 15 years of age, while in segment 4 there is a high percentage of vehicles aged from 6 to 10 years.

Table 10.

Structure of the segments on account of the average annual mileage of the vehicle

\begin{tabular}{|c|c|c|c|}
\hline \multirow{2}{*}{ Segment } & \multicolumn{3}{|c|}{ Average annual mileage } \\
\cline { 2 - 4 } & Up to $\mathbf{1 5 . 0 0 0} \mathbf{~ k m}$ & $\mathbf{1 6 . 0 0 0 - 3 0 . 0 0 0} \mathbf{~ k m}$ & Above 30.000 km \\
\hline $\mathbf{1}$ & $50 \%$ & $35 \%$ & $16 \%$ \\
\hline $\mathbf{2}$ & $52 \%$ & $29 \%$ & $19 \%$ \\
\hline $\mathbf{3}$ & $41 \%$ & $43 \%$ & $16 \%$ \\
\hline $\mathbf{4}$ & $33 \%$ & $55 \%$ & $12 \%$ \\
\hline In total & $42 \%$ & $43 \%$ & $15 \%$ \\
\hline
\end{tabular}

Source: authors' own study.

The analysis of table 10 shows that in segments 1 and 2, drivers making up to 15 thousand kilometres per year are dominant. In contrast, in segment 4 there are mostly respondents driving 16 to 30 thousand kilometres per year. 
Table 11.

Structure of the segments on account of the place where a vehicle is serviced

\begin{tabular}{|c|c|c|c|}
\hline \multirow{2}{*}{ Segment } & \multicolumn{3}{|c|}{ Place of service } \\
\cline { 2 - 4 } & $\begin{array}{c}\text { Authorized service } \\
\text { station }\end{array}$ & $\begin{array}{c}\text { Independent car repair } \\
\text { shop }\end{array}$ & Both options \\
\hline $\mathbf{1}$ & $33 \%$ & $29 \%$ & $38 \%$ \\
\hline $\mathbf{2}$ & $17 \%$ & $57 \%$ & $26 \%$ \\
\hline $\mathbf{3}$ & $25 \%$ & $33 \%$ & $41 \%$ \\
\hline $\mathbf{4}$ & $19 \%$ & $36 \%$ & $45 \%$ \\
\hline In total & $24 \%$ & $36 \%$ & $40 \%$ \\
\hline
\end{tabular}

Source: authors' own study.

The analysis of Table 11 indicates that in segment 1 , the fraction of the drivers servicing their cars in authorized or affiliated service stations is definitely the largest among all segments. Regarding segment 2, this consists mostly of persons taking advantage of the services provided by independent car repair shops. Segments 3 and 4 are close to the sample in terms of considered fractions.

\section{Conclusions}

In consequence of the carried out analysis, we identified 4 segments of consumers in the motor oil market for passenger cars, specific in terms of motivation loyalty as measured by means of the L indicator adopted from NPS (Reichheld, 2003). The afore-mentioned segments are:

1. Segment 1 - rational promoters $(\mathrm{L}=8,91)$. This segment covers, above all, older, well-educated consumers driving the newest higher classes cars, albeit at lesser mileages.

2. Segment 2 - emotional promoters $(L=8,21)$. In this segment we are very often dealing with young persons who are ecologically-oriented, as well as sports-oriented. They make smaller mileages, often use older cars and they take advantage of the services provided by independent car repair shops.

3. Segment 3 - destroyers $(L=3,61)$. This segment gathers together middle-aged persons who often consider themselves as being cost-effective. They frequently drive newer vehicles and make average mileages.

4. Segment 4 - neutral $(\mathrm{L}=6,79)$. The most "typical" group. In terms of sex, age, education and self-assessment as a driver, members of this group are close to the sample. The persons included in this segment mainly use cars from the lower segments of the market, purchased as used cars.

Practical implication consists in the demonstration of the heterogeneous structure of the market that should address the application of various marketing tools towards various segments. 


\section{Acknowledgements}

The study financed by Valvoline.

\section{References}

1. Assael, H. (1973). Segmenting market segmentation. Strategies and techniques. European Research Marketing - Advertising, 5, 28-35.

2. Assael, H., and Roscoe, M. (1976). Approaches to Market Segmentation Analysis. Journal of Marketing, 40(4), 67-76. doi: 10.1177/002224297604000408.

3. Dziechciarz, M. (2009). Podejścia do oceny atrakcyjności segmentów rynku jako etapu kończącego proces segmentacji rynku. Prace Naukowe Uniwersytetu Ekonomicznego we Wroctawiu, 51, 14-27.

4. Encyklopedia zarządzania (2019). Segmentacja rynku. http://mfiles.pl, 23.01.2020.

5. Gore, P. (2000). Cluster Analysis. In: H. Tinsley, and S. Brown, S. (eds.), Handbook of Applied Multivariate Statistics and Mathematical Modeling. San Diego: Academic Press.

6. Grzywacz, J. (2014). Segmentacja na rynku usług bankowych. Zeszyty Naukowe PWSZ w Płocku - Nauki Ekonomiczne, XX, 37-53.

7. Kierunek Chemia (2019). Rynek olejów smarowych w 2018 roku. www.kierunekchemia.pl/ artykul,62860,rynek-olejow-smarowych-w-2018-roku.html, 24.10.2019.

8. Kotler, P. (1994). Marketing. Analiza, planowanie, wdrażanie i kontrola. Warszawa: Gebethner.

9. Łapczyński, M. (2002). Badania segmentów rynku motoryzacyjnego z zastosowaniem drzew klasyfikacyjnych (CART). Zeszyty Naukowe Akademii Ekonomicznej w Krakowie, 586, 87-102.

10. Lotko, M., Lotko, A., and Lotko, W. (2020), Kryteria wyboru olejów silnikowych do samochodów osobowych. Radom: INW Spatium.

11. Migut G. (2004). Jak znaleźć podobnych klientów, czyli metody segmentacji. Materiały szkoleniowe Statsoft. Kraków: Statsoft.

12. Mynarski, S. (ed.) (1993). Analiza rynku. Systemy i mechanizmy. Kraków: Wydawnictwo Akademii Ekonomicznej.

13. Pawlak, J. (1992). Marketingowa segmentacja rynku. Annales Universitatis Mariae CurieSkłodowska - Sectio H: Oeconomia, 26, 159-173.

14. POPiHN (2018). Przemyst i handel naftowy. Raport roczny. Warszawa: Polska Organizacja Przemysłu i Handlu Naftowego. 
15. Reichheld, F. (2003). The One Number You Need to Grow. Harvard Business Review, December.

16. Smith, W. (1956). Product Differentiation and Marketing Segmentation as Alternative Marketing Strategies. Journal of Marketing, 21(1), 3-8.

17. Smyczek, S. (2000). Typologia konsumentów indywidualnych na rynku usług bankowych. Marketing i Rynek, 7, 16-23.

18. Szulce, H., Florek, M., and Walkowiak, K. (2004). Segmentacja jako podstawa zróżnicowania działań marketingowych. Acta Universitasis Lodziensis - Folia Oeconomica, 179, 273-284.

19. Webranking (2019). Oleje silnikowe - ranking popularności. https://webranking.pl/2110oleje-silnikowe.html, 26.10.2019.

20. Wedel, M., and Kamakura, W. (1998). Market Segmentation. Conceptual and Methodological Foundations. Boston-Dordrecht-London: Kluwer.

21. Wybór Kierowców (2019). Klasyfikacja marek olejów silnikowych. http://www.wyborkierowcow.pl, 26.10.2019.

22. Żuchowski, P. (2007). Segmentacja rynku - ujęcie teoretyczne. Zeszyty Naukowe Wyższej Szkoły Społeczno-Ekonomicznej w Ostrołęce, 4, 119-132. 